\author{
Michał Januszkiewicz \\ Uniwersytet Adama Mickiewicza \\ aramis69m@gmail.com
}

\title{
Wobec strukturalizmu
}

\section{Towards Structuralism}

\begin{abstract}
The article is an attempt at reinterpretation of structuralism (particularly in the literary studies) from the perspective of a former critic of this theory. And although various doubts related to the concepts of structuralism aren't dispelled, the author points to the undoubtedly valuable research achievements within this trend, concerning the problems of defining text, genology, or versology.
\end{abstract}

Keywords: structuralism, hermeneutics, text, interpretation, method

Streszczenie: Artykuł jest próbą ponownej interpretacji strukturalizmu (szczególnie w badaniach literackich) z perspektywy dawnego krytyka tej teorii. I choć rozmaite wątpliwości związane z koncepcjami strukturalizmu nie zostają tu rozwiane, to jednak autor wskazuje niewątpliwie wartościowe dokonania badawcze w obrębie tego kierunku dotyczące zagadnień definiowania tekstu, genologii czy wersologii.

Słowa kluczowe: strukturalizm, hermeneutyka, tekst, interpretacja, metoda

\section{Patrząc z ukosa}

Nie ukrywam, że czuję się dość mocno skonfundowany, będąc wywołanym „do tablicy” w sprawie tak ważnej i poważnej jak strukturalizm, czy szerzej: orientacja strukturalno-semiotyczna. Czuję onieśmielenie i brak uprawnienia. Przynajmniej z trzech powodów.

Po pierwsze dlatego, że przez długie lata pozostawałem krytyczny wobec tej wielkiej tradycji i myśli, która nadawała fundamentalny kształt nie tylko zachodnioeuropejskiemu, ale przede wszystkim - polskiemu literaturoznawstwu, polskiej teorii literatury. 
Po drugie, jestem świadom czynionych przez przedstawicieli polskiego strukturalizmu podsumowań, ocen i rozwinięć. Cóż mogę jeszcze dodać wobec niesłabnącej aktywności naukowej Edwarda Balcerzana, Seweryny Wysłouch ${ }^{1}$ czy ważnych głosów w sprawie strukturalizmu Janusza Sławińskiego $^{2}$ i Michała Głowińskiego, którego wystąpienia zatytułowanego Kilka stów o strukturalizmie $w$ nauce o literaturze miałem zaszczyt wystuchać podczas wręczenia profesorowi doktoratu honoris causa na Uniwersytecie Kazimierza Wielkiego w Bydgoszczy 25 kwietnia 2018 roku. Nie wolno w tym miejscu pominąć ważnej pracy zbiorowej o strukturalizmie w Europie Środkowej pod redakcją Danuty Ulickiej i Włodzimierza Boleckiego³.

Trzecim powodem mojej konfuzji jest fakt, że lektura tekstu Thomasa Pavla poświęconego strukturalizmowi, a zatytułowanego Porzadek języka wzbudziła we mnie pewien niepokój i smutek. Niepokój i niezgodę wywołało niesłuszne, jak mniemam, rozmycie przez autora granicy między strukturalizmem a poststrukturalizmem. Smutek zaś wiąże się z rozczarowaniem, że nie promowano w świecie wielkich i niewątpliwych osiągnięć polskiej nauki, w tym właśnie polskiej wersji strukturalizmu. Gdyby było inaczej, tekst Thomasa Pavla musiałby zostać napisany od nowa, a w konsekwencji przełożyłby się, mam taką nadzieję, na inną ocenę strukturalizmu. Gdyby jednak spojrzeć inaczej: czy mam się czuć jako występujący w roli adwokata diabła? Już nie.

Po latach mój krytyczny stosunek do strukturalizmu nie tylko osłabł, ale też przerodził się w szczególny szacunek, zrozumienie, a nawet sympatię. W okresach przejściowych, gdy przekształceniom ulegają naukowe paradygmaty, młodzi „bojownicy” nauki, poszukując własnego języka wyrazu i sposobu realizowania własnych pomysłów naukowych ${ }^{4}$, koncentrują się w dużej mierze na różnych sposobach upozowania przeciwnika, dzięki czemu zdolni są zbudować własne wyraziste stanowisko. Nawiasem mówiąc, prawdy tej nauczyłem się kiedyś od Edwarda Balcerzana. Takim „upozowanym” przeciwnikiem był dla mnie właśnie strukturalizm. Gdy jednak czas buntu mija, można zobaczyć rzeczy, które dotąd skrywało „waleczne zaślepienie”. Jeżeli więc w końcu miałbym uznać prawo do zabrania bardzo skromnego głosu w sprawie paradygmatu strukturalno-semiotycznego, to jedynie na mocy trojakiego uzasadnienia.

Pierwszym jest fakt, że zostałem wychowany w szkole strukturalno-semiotycznej na Wydziale Filologii Polskiej i Klasycznej w Poznaniu, który był najważniejszym (obok warszawskiego Instytutu Badań Literackich) ośrodkiem

${ }^{1}$ W tym miejscu warto przywołać choćby kilka z wydanych ostatnio książek. Zob. E. Balcerzan, Literackość. Modele, gradacje, eksperymenty, Toruń 2013; tenże, Pochwata poezji. Z pamięci, z lektury, Mikołów 2013; S. Wysłouch, Wyprzedaż semiotyki, Poznań 2011; taż, Narracje mate i duże, Poznań 2015.

2 J. Sławiński, Co nam zostato ze strukturalizmu, „Teksty Drugie” 2001, nr 5.

3 Strukturalizm w Europie Środkowej i Wschodniej, red. D. Ulicka, W. Bolecki, Warszawa 2012.

${ }^{4}$ O sprawach tych pisał najciekawiej, jak wiadomo, Thomas S. Kuhn w Strukturze rewolucji naukowych, tłum. H. Ostromęcka, Warszawa 2009. 
myśli strukturalno-semiotycznej w Polsce. Miałem niewątpliwy zaszczyt i radość, wynikające z bycia (nieco krnąbrnym, ale chyba uważnym i zaciekawionym) uczniem takich nauczycieli, jak profesor Seweryna Wysłouch, promotorka moich prac - magisterskiej i doktoratu, założycielka i kierownik (od 1998 roku) Zakładu Semiotyki Literatury, w którym pracuję, czy profesor Edward Balcerzan, kierownik Zakładu Teorii i Historii Literatury XX Wieku, do którego należałem w latach 1993-1998.

Uzasadnienie drugie stanowi niezaprzeczalny fakt, że stojąc za młodu w opozycji do strukturalizmu, sam przynależałem do jego szeroko pojętej tradycji. We wspomnianym przeze mnie wyżej przemówieniu zatytułowanym Kilka stów o strukturalizmie Michał Głowiński słusznie zauważył, że strukturalistyczno-semiotyczna orientacja w badaniach literackich wyznaczyła zasadniczo dwie postawy: pozytywną (programową, aprobatywną i kontynuacyjna) i negatywną, czyli krytyczną. Chcąc nie chcąc, należę więc do strukturalistycznej tradycji.

Mam jednak i trzecie uzasadnienie. Po latach mój stosunek do strukturalizmu nie daje się dziś może określić jako konwersja, gdyż nie czuję się powracającym i skruszonym synem marnotrawnym; mimo to żywię wobec tej tradycji i tego myślenia dużą otwartość. Nieustannie poszukuję wspólnych dróg znajdując na przykład potwierdzenie dla możliwości istnienia tego, co nazywam semiotyką hermeneutyczną̧; nie ukrywam też, że w hermeneutycznej tradycji, do której przynależę i do której się przyznaję, dostrzegam miejsca domagające się wypełnienia. To te miejsca, w których brakuje hermeneutyce odniesień do ważnych i fundamentalnych pojęć tak istotnych dla strukturalizmu, semiotyki i fenomenologii, jak tekst i granice tekstu, dyskurs, narracja, analiza, fikcja, forma i język tekstu literackiego, sposoby funkcjonowania znaczeń. Staram się luki te wypełniać, odnosząc się na różne sposoby do - właśnie strukturalistycznej i fenomenologicznej - pojęciowości. Wydaje mi się bowiem, że, parafrazując Francisa Bacona, hermeneutyce nie tylko skrzydeł trzeba, ale i ołowiu. Trudno oczywiście nie zauważyć, że chociaż pojęcia te bywają przywoływane i analizowane w hermeneutyce, to dzieje się tak niezbyt często, a jeśli już, to przede wszystkim u Paula Ricoeura, który otwarcie przyznaje się wówczas właśnie do strukturalistycznej tradycji ${ }^{6}$. Zarazem (w przeciwieństwie

5 Zob. mój tekst Znaki interpretacja. Czy możliwa jest semiotyka hermeneutyczna [w:] M. Januszkiewicz, Być i rozumieć. Rozprawy i szkice z humanistyki hermeneutycznej, Kraków 2017.

${ }^{6}$ Zob. P. Ricoeur, Jezyk, tekst, interpretacja. Wybór pism, tłum. P. Graff, K. Rosner, Warszawa 1989; tenże, Model tekstu. Dziatanie znaczqce rozważane jako tekst, thum. J. Falkowska, „Pamiętnik Literacki” 1984, z. 2. Oczywiście, zwrócić należy uwagę na fakt, że problematyką tekstu zajmował się również Hans-Georg Gadamer, jednak bez związku z tradycją strukturalistyczną i w mało systematyczny sposób. Zob. na przykład: tenże, Tekst i interpretacja, tłum. P. Dehnel [w:] tegoż, Język i rozumienie, tłum. P. Dehnel, B. Sierocka, Warszawa 2003. Z kolei Wolfgang Iser, którego można zaliczyć do szeroko pojętej fenomenologii hermeneutycznej, odwołuje się w swych pracach do fenomenologicznych teorii tekstu. Zob. W. Iser, Apelatywna struktura tekstów [w:] Wspótczesna teoria badań literackich za granica, red. H. Markiewicz, t. 4, cz. 2, Kraków 1996. 
do ujęcia strukturalistycznego) kategorie te nie mogą być w hermeneutyce kategoriami metodologicznie „twardymi”, lecz interpretacyjnymi.

\section{Znaczenie strukturalizmu dla literaturoznawstwa}

Nie wiem, czy trzeba zadawać pytanie o to, czy strukturalizm wpłynął na unowocześnienie dyskursu literaturoznawczego, gdyż to, że wpłynął, i to w sposób istotny - nie powinno budzić niczyich wątpliwości. Należałoby raczej zapytać: jak wpłyną?? Przede wszystkim radykalnie przeobraził naukę o literaturze. Przezwyciężył (choć moim zdaniem z pewnymi zastrzeżeniami) obowiązujący wcześniej paradygmat pozytywistyczny, wpisujący się w przyrodoznawczy model nauk (oparty na koncepcji przyczynowości i praw oraz rozmaitego typu badaniach genetycznych, uosabianych przez socjologizm, biografizm czy historyzm). Wraz ze swoimi najbliższymi „krewniakami” - formalizmem i semiotyką oraz z zaprzyjaźnioną wersją fenomenologii (dokładniej: ingardenologią zinterpretowaną strukturalistycznie, ale nie tylko; jeszcze w okresie przedwojennym pewna część polskich badaczy pojmowała strukturalizm jako nurt wywodzący się z fenomenologii) - ustanowił nowoczesny model teorii literatury i nowy paradygmat literaturoznawczy. Jego zasadniczą zasługą było, mówiąc najogólniej, wykazanie, że badanie literatury może być uzasadnione jedynie od strony jej samej, a nie jakichś zewnętrznie warunkujących ją przyczyn. Literatura to zatem sprawa języka. We wczesnej fazie istnienia nowego paradygmatu pojawiło się w związku z tym przekonanie, że skoro tak, to literaturą zająć się powinni specjaliści od języka - językoznawcy, a szczególna część nauki o literaturze, poetyka, miałaby się stać, jak chciał tego Roman Jakobson, częścią językoznawstwa. Odkryty został, jeszcze za sprawą formalistów rosyjskich, język poetycki - nie jako po prostu jedna z odmian języka ogólnego (naturalnego), ale jako język odrębny. Stać się on mógł zatem osobnym przedmiotem badań, a teoria języka poetyckiego odegrała rolę szczególną także w polskim strukturalizmie ${ }^{7}$. Strukturalizm, czy szerzej: paradygmat formalno-strukturalno-semiotyczno-fenomenologiczny, mimo że przeciwstawił się obowiązującemu scjentystycznemu paradygmatowi naukowemu spod znaku pozytywizmu, sam nie zerwał z ideą nauki, lecz zradykalizował nawet naukowy ogląd świata. Można wręcz powiedzieć, że dzięki strukturalizmowi nauka o literaturze stała się nauką (pozwolę sobie w tym miejscu na kolokwializm) pełną gębą! Dzięki strukturalizmowi i semiotyce pogłębiony został namysł nad znakowym charakterem literatury ${ }^{8}$, a szczególną kategorią

7 Zob. J. Sławiński, Wokót teorii języka poetyckiego [w:] tegoż, Dzieło, język, tradycja, Warszawa 1974; tenże, Koncepcja języka poetyckiego awangardy krakowskiej, Kraków 1998 (pierwsze wydanie 1965).

8 Zob. S. Wysłouch, Literatura i semiotyka, Warszawa 2001. 
badawczą okazało się pojęcie tekstu' ${ }^{9}$ nawet bardziej tekstu niż znaku - jak przekonująco pokazuje to Seweryna Wysłouch ${ }^{10}$. Żaden nurt poza strukturalizmem nie zbudował tak konsekwentnej teorii wiersza (przed wojną - przede wszystkim Franciszek Siedlecki), a jego osiągnięcia w dziedzinie wersologii czy stylistyki wydają się bezsporne i niezrównane ${ }^{11}$, co słusznie zauważa Janusz Sławiński ${ }^{12}$. I wreszcie - chyba najważniejsze osiągnięcie polskiego strukturalizmu - to komunikacjonizm - szczególne i charakterystyczne dla polskiego strukturalizmu rozwinięcie, które dokonało się w obrębie tej szkoły. Dzieło literackie potraktowane zostało jako fakt komunikacji literackiej, co w konsekwencji pozwoliło wydobyć je z badań czysto immanentnych. Warto przy tym zauważyć, jak inwencyjnie rozwija się w strukturalizmie komunikacjonistycznym terminologia naukowa, by wymienić tu przykładowo kategorie „autora wewnętrznego" (termin Balcerzana), „podmiotu czynności twórczych” (pojęcie Sławińskiego), „podmiotu utworu”, „adresata utworu” czy „,czytelnika idealnego” (określenia Aleksandry Okopień-Sławińskiej) ${ }^{13}$.

Oczywiście, strukturalizm, który dominował w polskiej teorii literatury od mniej więcej końca lat pięćdziesiątych aż do końca lat osiemdziesiątych (wynik zaiste imponujący!), budził i budzić będzie rozmaite wątpliwości, a nawet niechęć. Nie uważam jednak, aby ten nurt polskiego literaturoznawstwa okazał się po prostu przeżytkiem. Owszem, wytracił zdecydowanie swój impet, ale przecież nie został zastąpiony przez inną tak spójną „matrycę dyscyplinarną" (by użyć terminu Thomasa S. Kuhna), gdyż poststrukturalizm był wielopostaciowy, a dominujący w nim nurt - dekonstrukcjonizm - nigdy w polskiej teorii literatury konsekwentnie się nie przyjął i po zainteresowaniu, jakie wzbudził, niewiele już śladu pozostało. To, co wydarzyło się w polskiej teorii literatury po strukturalizmie (aczkolwiek nie jestem przekonany, czy użycie słowa „po" jest w ogóle zasadne), to pewien pluralizm teoretyczny. Oprócz dekonstrukcjonizmu pojawiły się przecież choćby neopragmatyzm, konstruktywizm, nowy historyzm, postkolonializm czy feminizm; ale powróciła też dumnie hermeneutyka, przez lata wyłączona z głównego paradygmatu teoretycznego. W tej pluralistycznej sytuacji, w jakiej znalazła się współczesna

${ }^{9}$ Na ten temat zob. szerzej: M.R. Mayenowa, Struktura tekstu [w:] tejże, Poetyka teoretyczna. Zagadnienia języka, Wrocław 1979 (rozdział V); T. Dobrzyńska, Tekst. Próba syntezy, „Pamiętnik Literacki” 1991, z. 2; J. Łotman, Struktura tekstu artystycznego, tłum. A. Tanalska, Warszawa 1984, s. 76-79; R. Barthes, Teoria tekstu, tłum. A. Milecki [w:] Wspótczesna teoria badań literackich..., dz. cyt.

10 S. Wysłouch, Znak w teorii literatury [w:] Wgaszczu znaków, red. P. Orlik, Poznań 2004.

${ }^{11} \mathrm{~W}$ tym kontekście szczególnie zasługują na uwagę wydawane wielokrotnie i w ogromnych nakładach podręczniki do poetyki: Zarys teorii literatury i Poetyka stosowana. Zob. M. Głowiński, A. Okopień-Sławińska, J. Sławiński, Zarys teorii literatury, Warszawa 1986; B. Chrząstowska, S. Wysłouch, Poetyka stosowana, Warszawa 1978.

12 J. Sławiński, Co nam zostato..., dz. cyt., s. 15.

13 A. Okopień-Sławińska, Relacje osobowe w literackiej komunikacji [w:] Problemy teorii literatury, seria 2: Prace z lat 1965-1974, Wrocław 1987. 
teoria literatury, zrobiło się również miejsce dla starego, dobrego strukturalizmu, który zwyczajnie musiał się nieco posunąć albo - by nie czynić tu aluzji do wieku - po prostu pozostawić wolną przestrzeń także innym. Ta sytuacja dowodzi nie tylko utraty przez strukturalizm monopolu na uprawianie teorii literatury, lecz także żywotności tego stylu badawczego.

\section{Łyżka dziegciu albo dlaczego nie zostałem jednak strukturalistą?}

Obecnie strukturalizm musi się pogodzić z faktem, że nie jest, a może i nigdy nie był - by odwołać się do Thomasa Pavla - „dyskursem naukowego zbawienia”. Czy oznacza to jednak, że uprawiał, jak mówi wspomniany badacz, „retorykę końca”, która służyła marginalizacji innych teoretycznych nurtów? Czy budując swój gmach „wiedzy”, nie domagał się także wyłącznej władzy? Sądzę, że takie sugestie po części są nieuzasadnione, gdyż trudno nie zauważyć, że uprawiana przez lata strukturalistyczna teoria literatury sprawiała wrażenie, jak gdyby była jedyną możliwą i całkowicie neutralną. Gdy otworzymy najważniejszy strukturalistyczny podręcznik zatytułowany Zarys teorii literatury, nie odnajdziemy w nim deklaracji dotyczących metodologicznych założeń. Podobnie ma się rzecz z Poetyką stosowanq Bożeny Chrząstowskiej i Seweryny Wysłouch. Gwoli sprawiedliwości dodać warto, że takie upozycjonowanie metodologiczne odnajdziemy jednak bez trudu w książce Edwarda Balcerzana Kregi wtajemniczenia, gdzie autor pokazuje, że każdy powinien... zostać strukturalistą ${ }^{14}$. Strukturalizm pojawił się w czasach, w których wiara w obiektywizm, twardą teorię i twarde pojęcia cieszyła się jeszcze ogromną popularnością. Jednakże: czy zbudowany przez strukturalistów „kościół nauki” nie wyparł się humanistycznych ideałów? Czy unieważniając paradygmat pozytywistyczny, sam nie proponował nowej wersji scjentyzmu? Czy niesłusznie nie zlekceważył swojego sojusznika w walce z pozytywizmem - hermeneutyki - która pragnęła widzieć w naukach o duchu nauki o rozumieniu sensu wszelkich zobiektywizowanych wytworów ducha ludzkiego, do których dostęp nie może się odbywać na gruncie dualizmu podmiotowo-przedmiotowego i zneutralizowanej obiektywizacji przedmiotu poznawanego przez jakiś zdepersonalizowany podmiot epistemologiczny? Czy istoty rozumienia, o którym mówi się $\mathrm{w}$ humanistyce zorientowanej hermeneutycznie, nie stanowi bowiem fakt,

${ }_{14}$ E. Balcerzan, I ty zostaniesz strukturalista [w:] tegoż, Kręgi wtajemniczenia. Czytelnik, badacz, ttumacz, pisarz, Kraków 1982. Oczywiście, należy zwrócić uwagę na żartobliwość tytułu, który nawiązuje ponadto do książki Wiktora Woroszylskiego I ty zostaniesz Indianinem. 
że każde rozumienie jest już zawsze samorozumieniem i że rozumienie nie rozpoczyna się nigdy od punktu „zero”? Czy strukturalizm nie kontynuował $\mathrm{w}$ istocie ducha pozytywistycznego $i$ charakterystycznego dla nauk apriorycznych i przyrodniczych wyjaśniania (przy całej dzisiejszej świadomości tego, że opozycja wyjaśniania i rozumienia nie daje się obecnie dłużej utrzymać)?

Istnieją zatem powody, dla których nie zostałem strukturalistą. To powody natury metodologicznej, a może po prostu również - rzecz odmiennego naukowego gustu... Strukturalizm (lecz niekoniecznie - semiotyka) wydaje się stać na straży nauki pojętej w kategoriach monodyscyplinarnych, podczas gdy przypadek literaturoznawstwa wskazuje raczej na oczywistość badań interdyscyplinarnych. Badanie literatury sprowadzające się do przewodnictwa po strukturze utworu czy strukturach „wyższego rzędu” bywa nudne i lekturowo nieprzyswajalne (czego dowiódł Roman Jakobson, interpretując sonet Charles’a Baudelaire’a Koty i wskazując tu na przykład „ścisły związek między rozkładem rymów a wyborem kategorii gramatycznych"15; złośliwi mówili, że wskutek Jakobsonowskiej analizy koty po prostu uciekły w panice z samego wiersza). Przede wszystkim jednak jest niezdolne do widzenia jej w horyzoncie aksjologii, etyki czy tego wszystkiego, co wiąże ją nierozerwalnie ze sprawą ludzkiej egzystencji. A w tym kontekście opanowanie warsztatu analitycznego i pojęć poetyki okazuje się niewystarczające. Zarówno strukturalizm, jak i hermeneutyka za podstawę swojego namysłu uznają język. Trudno mi jednak zgodzić się ze strukturalistycznym zredukowaniem języka albo do narzędzia, albo do systemu, pewnej ponadosobowej i ponadegzystencjalnej gramatyki. Tymczasem bliskie mi myślenie hermeneutyczne pojmuje język jako to, do czego już w istotny sposób przynależymy. Język jest tym, co wyznacza charakter ludzkiego bycia-w-świecie. Człowiek bowiem to - jak pokazują to Martin Heidegger czy Hans-Georg Gadamer - istota, która pojmuje swoje bycie i jego sens na sposób językowy. Zatem zasadniczym rysem języka jest jego wymiar egzystencjalny ${ }^{16}$. Trudno mi także zaakceptować metodologiczne rozróżnienia przyjmowane przez strukturalizm. Pisał już o tym Andrzej Szahaj, a ja pozwolę sobie jedynie potwierdzić jego zastrzeżenia ${ }^{17}$. Trudno mi zgodzić się na przyjmowany przez strukturalizm (w Polsce mam tu na myśli propozycje Janusza Sławińskiego) dualizm metodologiczny, zmuszający do wyraźnego

15 R. Jakobson, C. Levi-Strauss, „Koty” Baudelaire’a, tłum. M. Żmigrodzka [w:] Sztuka interpretacji, t. 1, wyb., oprac. H. Markiewicz, Wrocław 1971, s. 563-581.

16 Zob. M. Heidegger, Bycie i czas, tłum. B. Baran. Warszawa 1994 (zob. na przykład $\$ 33)$; tenże, History of the Concept of Time. Prolegomena, tłum. T. Kisiel, Bloomington, Indianapolis 1992, s. 261 i n.; zob. też mój tekst „Bytem, który może być rozumiany, jest język". Zwrot lingwistyczny w hermeneutyce [w:] M. Januszkiewicz, W poszukiwaniu sensu. Phronesis i hermeneutyka, Poznań 2016.

17 A. Szahaj, Stawiński o interpretacji. Analiza krytyczna [w:] tegoż, O interpretacji, Kraków 2014. 
odróżnienia poziomu analizy (względnie opisu), jako tego, co bezpośrednio i naocznie w tekście dane (obserwowalne), od poziomu interpretacji jako - w gruncie rzeczy - domeny woli. Strukturalizm siłą rzeczy osłabiać będzie (w metodologicznym sensie) pojęcie interpretacji, sprowadzając ją do, co najwyżej, pożytecznego komentarza albo, „co najniżej”, do gwałtu na tekście. Wydaje się tymczasem, że rzecz ma się zgoła inaczej: porządek opisowo-analityczny nie daje się oddzielić od porządku interpretacyjnego. Dzieje się tak dlatego, że opis, który adekwacyjnie miałby się odnosić do rzeczy takich, jakimi są (tu: do tekstu), nie istnieje. Nie ma opisu czy analizy, które nie byłyby już jakoś „ustawione” za sprawą interpretacyjnych założeń (na przykład selekcji tego, co obserwujemy, perspektywy, którą przyjmujemy, czy wstępnego rozumienia tego, co w ogóle mamy obserwować). Nie będę również ukrywał, że strukturalizm nawet w swej zreformowanej „komunikacjonistycznej” wersji mnie nie przekonał. Docenić z pewnością należy jego inwencję terminologiczną i badawczą pasję, o czym była już wyżej mowa. Co z tego jednak, skoro nawet w tej wersji strukturalizm mimo wszystko pozostał na stanowisku uprzywilejowującym tekst jako stabilną strukturę. W tym kontekście śmiałe pomysły teoretyka recepcji, a zarazem przedstawiciela fenomenologii hermeneutycznej, Wolfganga Isera, poszły zdecydowanie dalej ${ }^{18}$. Strukturalizm nigdy nie zdobył się ani na trans- czy interakcyjne ujęcie relacji między tekstem a odbiorcą/interpretatorem, ani na osłabienie granic między nimi - pozostał wierny twardemu metodologicznemu rozdwojeniu na podmiot i przedmiot. Metodologiczne kwestie ogólnej natury przekładają się także na te szczegółowe. Egzystencjalne czy hermeneutyczne pojmowanie literatury wiąże ją nierozerwalnie z człowiekiem. Stąd atencja, którą obdarzyć należy postać literacką. Niestety, strukturalizm nie poradził sobie z tym problemem: człowieka zastępował abstrakcyjną kategorią podmiotu (na przykład lirycznego), a postać literacką sprowadzał, jak czynił to na przykład Roland Barthes, do funkcji struktury utworu podporządkowanej fabule. Nie ma oczywiście najmniejszych wątpliwości, że postać literacka to wprawdzie figura tekstowa, ale reprezentująca człowieka w jego rozmaitych przejawach bycia-w-świecie. Można by nawet powiedzieć, że postać literacka właśnie dlatego, że jest figurą tekstową, której przysługuje istnienie fikcjonalne, w sposób szczególny wzmacnia pytania o człowieczeństwo. Dzieje się tak dlatego, że postać literacka jako postać fikcyjna nagromadza i uwypukla znaczenia oraz wartości (egzystencjalne, metafizyczne, etyczne, estetyczne itd.), które niejako rozmywają się czy tracą swą uchwytność na poziomie życia realnego (niefikcjonalnego).

Nie potrafię się wyzbyć pytań, wątpliwości czy nawet protestu wobec rozmaitych przekonań żywionych przez strukturalizm. Można by wszak powiedzieć, że pozostają one jednak na dużym stopniu uogólnienia. A czy jako

${ }_{18}$ Zob. W. Iser, Act of Reading. A Theory of Aesthetic Response, Baltimore 1978. 
hermeneuta mam prawo zadowalać się tymi uogólnieniami? A może jest tak, że przywoływany już wcześniej polski strukturalizm uniknął wielu pułapek strukturalizmu francuskiego, o których wspomina Thomas Pavel.

\section{Przez znaki do człowieka ${ }^{19}$}

Przede wszystkim polski strukturalizm nie dał się wciągnąć w zasadzkę lingwistyki - jedynym wyjątkiem był przedwojenny badacz, którego nazwać by można pierwszym polskim strukturalistą - Franciszek Siedlecki. Ten wybitny teoretyk wiersza popełnił, jak się wydaje, najwięcej grzechów strukturalizmu, które wyżej wymieniłem. Jednakże strukturalizm powojenny, owszem, korzystał (i korzysta) z osiągnięć językoznawstwa, jednak nie przeniósł na grunt literaturoznawstwa „twardej” nauki o systemie językowym (Ferdinand de Saussure), który ruguje czy całkowicie podporządkowuje sobie to, co jednostkowe. Strukturalistyczna teoria literatury w Polsce nigdy nie kwestionowała znaczenia pojedynczych dzieł literackich. Nie tylko chętnie je analizowała, ale i dostrzegała, że to, co jednostkowe (dzieło, arcydzieło), posiada moc wpływająca na zmianę systemu literackiego. W przywoływanym już wcześniej przeze mnie wystąpieniu o strukturalizmie Głowiński zaprzecza także temu, jakoby polski strukturalizm stał na stanowisku radykalnie antyhistorycznym. Przeciwnie, strukturalizm starał się śledzić ewoluowanie literackich struktur (konwencji, gatunków, stylów). O ile de Saussure opowiadał się za uprzywilejowaniem synchronii nad diachronią, o tyle polski strukturalizm (na przykład Sławiński) podkreślał znaczenie tradycji i diachronii ${ }^{20}$, a Edward Balcerzan z upodobaniem zajmuje się nie tylko teorią, ale i historią literatury. Z kolei atakowany za immanentyzm strukturalizm przeobraża się - za sprawą semiotyki uprawianej przez Sewerynę Wysłouch - w krytykę werbocentryzmu i analizę oraz interpretację dialogu intersemiotycznego, pochwałę zwrotu ikoniczne$\mathrm{go}^{21}$. Nie rezygnuje również z odniesień społecznych, przy czym nie powraca do jakiegoś anachronicznego socjologizmu, badającego wpływ społeczeństwa na literaturę, lecz poszukuje drogi w drugą stronę. Przekracza immanentyzm

19 Podtytuł jest aluzją do dedykacji, którą napisała dla Edwarda Balcerzana Maria R. Mayenowa w podarowanym mu egzemplarzu Poetyki teoretycznej: „przez znaki do żywego człowieka”. Dedykacja jest zarazem i inną aluzją: przywołuje tytuł książki habilitacyjnej Edwarda Balcerzana: Przez znaki. Granice autonomii sztuki poetyckiej. Na materiale polskiej poezji wspótczesnej.

${ }^{20}$ Zob. J. Sławiński, Synchronia i diachronia w procesie historycznoliterackim [w:] Problemy teorii literatury, dz. cyt.; tenże, Dzieło. Język. Tradycja, dz. cyt.

${ }^{21}$ Zob. S. Wysłouch, Literatura a sztuki wizualne. Warszawa 1994; taż, Literatura i semiotyka, dz. cyt. 
za sprawą badań intertekstualnych ${ }^{22}$. Wreszcie na koniec, nie tylko jest komplementarnym wobec hermeneutyki językiem teoretycznym, ale także może zbliżać się do niej zawsze wtedy, gdy podziela z nią zainteresowanie problemem języka i podejmuje się zadań interpretacyjnych.

Nie widzę powodu, by - jak Thomas Pavel - sądzić, że zasadnie można dziś zacierać różnice między strukturalizmem a poststrukturalizmem, przynajmniej w Polsce. Tak jak nie ma powodu uważać, że manicheizm jest po prostu kontynuacją chrześcijaństwa, a nie herezją. Poststrukturalizm, zwłaszcza w swej wersji dekonstrukcyjnej, mimo że posługiwał się chętnie pojęciami strukturalizmu, okazał się po prostu zarówno strukturalistyczną (zanegowanie struktury), jak i hermeneutyczną (zakwestionowanie sensu) herezją, choć z pewnością wprowadził ważnego ducha krytycznego. Co zaś do strukturalizmu: choć musiał ustąpić miejsca innym językom teoretycznym, to przecież nadal i z powodzeniem może być uprawiany (choćby w poetyce). Zwłaszcza że, jak się wydaje i co pokazują prace takich badaczy, jak Balcerzan, Głowiński, Sławiński czy Wysłouch, zrezygnował już ze scjentystycznych marzeń, ale nie z krytycznego i pełnego zaciekawienia oglądu świata i literatury. Dlatego też wróżę mu lepszą przyszłość niż efemerycznym - politycyzującym i genderowym modom czy zwrotom.

\section{Bibliografia}

Balcerzan E., I ty zostaniesz strukturalistą [w:] tegoż, Kręi wtajemniczenia, Kraków 1982. Balcerzan E., Literackość. Modele, gradacje, eksperymenty, Toruń 2013.

Balcerzan E., Pochwata poezji. Z pamięci, z lektury, Mikołów 2013.

Barthes R., Teoria tekstu, tłum. A. Milecki [w:] Wspótczesna teoria badań literackich za granica, red. H. Markiewicz, t. 6, cz. 2, Kraków 1996.

Chrząstowska B., Wysłouch S., Poetyka stosowana, Warszawa 1978.

Dobrzyńska T., Tekst. Próba syntezy, „Pamiętnik Literacki” 1991, z. 2.

Gadamer H.-G., Tekst i interpretacja, tłum. P. Dehnel [w:] tegoż, Jezzkk i rozumienie, tłum. P. Dehnel, B. Sierocka, Warszawa 2003.

Głowiński M., O intertekstualności, „Pamiętnik Literacki” 1986, z. 4.

Głowiński M., Okopień-Sławińska A., Sławiński J., Zarys teorii literatury, Warszawa 1986.

Heidegger M., Bycie i czas, tłum. B. Baran, Warszawa 1994.

${ }_{22}$ M. Głowiński, O intertekstualności, „Pamiętnik Literacki” 1986, z. 77 (4); H. Markiewicz, Odmiany intertekstualności, w: tegoż, Literaturoznawstwo i jego sassiedztwa, Warszawa 1989; R. Nycz, Intertekstualność i jej zakresy. Teksty, gatunki, światy, w: tegoż, Tekstowy świat. Poststrukturalizm a wiedza o literaturze, Warszawa 1993. 
Heidegger M., History of the Concept of Time. Prolegomena, tłum. T. Kisiel, Bloomington, Indianapolis 1992.

Iser W., Act of Reading. A Theory of Aesthetic Response, Baltimore 1978.

Iser W., Apelatywna struktura tekstów [w:] Wspótczesna teoria badań literackich za granica, red. H. Markiewicz, t. 4, cz. 2, Kraków 1996.

Jakobson R., Levi-Strauss C., „Koty” Baudelaire’a, tłum. M. Żmigrodzka [w:] Sztuka interpretacji, t. 1, wyb., oprac. H. Markiewicz, Wrocław 1971.

Januszkiewicz M., Być i rozumieć. Rozprawy i szkice z humanistyki hermeneutycznej, Kraków 2017.

Januszkiewicz M., W poszukiwaniu sensu. Phronesis i hermeneutyka, Poznań 2016. Kuhn T.S., Struktura rewolucji naukowych, tłum. H. Ostromęcka, Warszawa 2009.

Mayenowa M.R., Struktura tekstu [w:] tejże, Poetyka teoretyczna. Zagadnienia jezzyka, Wrocław 1979.

Łotman J., Struktura tekstu artystycznego, tłum. A. Tanalska, Warszawa 1984.

Okopień-Sławińska A., Relacje osobowe w literackiej komunikacji [w:] Problemy teorii literatury, seria 2: Prace z lat 1965-1974, Wrocław 1987.

Markiewicz H., Odmiany intertekstualności [w:] tegoż, Literaturoznawstwo i jego sqsiedztwa, Warszawa 1989.

Nycz R., Intertekstualność i jej zakresy. Teksty, gatunki, światy [w:] tegoż, Tekstowy świat. Poststrukturalizm a wiedza o literaturze, Warszawa 1993.

Ricoeur P., Jezyk, tekst, interpretacja. Wybór pism, tłum. P. Graff, K. Rosner, Warszawa 1989.

Ricoeur P., Model tekstu. Dziatanie znaczace rozważane jako tekst, tłum. J. Falkowska, „Pamiętnik Literacki” 1984, z. 2.

Sławiński J., Co nam zostało ze strukturalizmu, „Teksty Drugie” 2001, nr 5.

Sławiński J., Koncepcja języka poetyckiego awangardy krakowskiej, Kraków 1998.

Sławiński J., Wokót teorii języka poetyckiego [w:] tegoż, Dzieto, język, tradycja, Warszawa 1974.

Strukturalizm w Europie Środkowej i Wschodniej, red. D. Ulicka, W. Bolecki, Warszawa 2012.

Szahaj A., Stawiński o interpretacji. Analiza krytyczna [w:] tegoż, O interpretacji, Kraków 2014.

Wysłouch S., Literatura a sztuki wizualne, Warszawa 1994.

Wysłouch S., Literatura i semiotyka, Warszawa 2001.

Wysłouch S., Narracje mate i duże, Poznań 2015.

Wysłouch S., Wyprzedaż semiotyki, Poznań 2011.

Wysłouch S., Znak w teorii literatury [w:] W gaszczu znaków, red. P. Orlik, Poznań 2004. 